\title{
D-carvone, a Monoterpene Reverses Alterations in Heart Rate, Nitric Oxide, Aortic Lipids and Enzymatic Antioxidant Status in Nitric Oxide Deficient Hypertensive Rats
}

\author{
Thiyagarajan Rajeshwari, Boobalan Raja* \\ Department of Biochemistry and Biotechnology, Faculty of Science, Annamalai University, \\ Annamalainagar-608 002, Tamil Nadu, India \\ Phone: +918940839994 Fax: +914144238080 \\ *E-mail address: drrajaau@gmail.com
}

\begin{abstract}
The present study was aimed to assess the antihyperlipidemic, antihypertensive and antioxidant effect of D-carvone, a monoterpene against $\mathrm{N}^{\omega}$-nitro-L-arginine methyl ester hydrochloride (LNAME) induced hypertension. Hypertension was prompted in adult male albino rats of the Wistar strain by oral administration of the L-NAME $(40 \mathrm{mg} / \mathrm{kg}$ body weight) in drinking water for 4 weeks. Rats were treated with D-carvone $(5,10$ and $20 \mathrm{mg} / \mathrm{kg}$ body weight) for four weeks. L-NAME treated rats exhibited significant increase in water intake, heart rate, aortic lipids level such as triglycerides (TG), total cholesterol (TC), free fatty acids (FFA) and significant decrease in the level of phospholipids (PL), plasma nitric oxide (NO). The activities of superoxide dismutase (SOD), catalase (CAT) and glutathione peroxidase (GPx) were decreased in erythrocytes of L-NAME induced hypertensive rats. Treatment with D-carvone restored all the above parameters to near normal level. These results suggest that D-carvone acts as an antihyperlipidemic, antihypertensive and antioxidant agent against L-NAME induced hypertensive rats.
\end{abstract}

Keywords: L-NAME; Lipids; Nitric oxide; Antioxidant; D-carvone

\section{INTRODUCTION}

Hypertension is one of the most important risk factors for CVD ( $\mathrm{Gu}$ et al., 2002). It afflicts more than 1 billion adults world-wide and $90-95 \%$ of these patients have essential hypertension (Whitworth, 2003). Dyslipidemia is a broad term which implies imbalance between elevated circulating levels of cholesterol and it occurs concomitantly in over onethird of patients with hypertension (Wong et al., 2006). The primary function of nitric oxide is the regulation of vascular tone, inhibition of VSMC proliferation and platelet aggregation (Dias-Junior et al., 2008) which makes chronic inhibition of basal nitric oxide with an orally active nitric oxide synthase inhibitor (L-NAME), a particularly interesting model of hypertension. Bioavailability of NO can be maintained by inhibition of oxidative stress, and therefore the agents with antioxidant properties inactivating free radicals increase NO bioavailability and can improve regulation of vascular tone (Kumar et al., 2010). 
Recent evidence indicates that oxidative stress as the main mechanism is responsible for cardiovascular complications such as alteration in lipid metabolism (Palmieri et al., 2006). Oxidative stress, originally described as an altered balance between the production of free radicals and antioxidant defenses, is an important phenomenon in different physiological and pathological processes (Chang and $\mathrm{Wu}, 2006$ ). In hypertensive animals, reactive oxygen species (ROS) are increased and superoxide dismutase, which converts $\mathrm{O}_{2}$ to $\mathrm{H}_{2} \mathrm{O}_{2}$, is reduced, suggesting that an imbalance between oxidant and antioxidant mechanisms is a contributing factor (Beswick et al., 2001; Thakali et al., 2006).

Many researchers are actively looking for antihypertensive compounds derived from various natural products for the use in functional foods (Diebolt et al., 2001; Grassi et al., 2005). In recent years, the prevention of cardiovascular diseases has been associated with ingestion of fresh fruits, vegetables or plants rich in natural antioxidants. The use of natural products as an alternative to the conventional treatment of cardiovascular diseases has been on the rise in the past few decades. Monoterpenes are primary compounds of plant essential oils and the effects of many medicinal herbs have been attributed to them. D-carvone is a monoterpene, present in the essential oils of many medicinal and aromatic plants (Caraway, dill and spearmint) that are endowed with many biological activities including antioxidant, antimicrobial, fungicidal, insecticidal (Johri, 2011) and anticancer properties (Vinothkumar et al., 2013). D-carvone has long been used as a natural medicine for the treatment of many acute, as well as chronic conditions. These include diabetes and cancer (Muruganathan et al., 2013; Vinoth kumar et al., 2013). Therefore, in the present study we investigated the effects of D-carvone on heart rate, lipid level, nitric oxide and enzymatic antioxidants in nitric oxide deficient hypertensive rats.

\section{MATERIALS AND METHODS}

\subsection{Source of chemicals and experimental animals}

D-carvone and L-NAME were purchased from Sigma-Aldrich (St. Louis, Missouri, USA). All other chemicals used in this study were of analytical grade obtained from Merck and Himedia, India.

Male albino ( 9 weeks-old) rats of Wistar strain with a body weight ranging from 180 to $220 \mathrm{~g}$ were procured from the Central Animal House, Department of Experimental Medicine, Rajah Muthiah Medical College and Hospital, Annamalai University, and were maintained in an airconditioned room $\left(25 \pm 1^{\circ} \mathrm{C}\right)$ with a $12 \mathrm{~h}$ light/12 h dark cycle. Food and water were provided ad libitum to all the animals. The study was approved by the Institutional Animal Ethics Committee of Rajah Muthiah Medical College and Hospital (Reg No.160/1999/CPCSEA, proposal number: 1082), Annamalai University, Annamalainagar.

\subsection{Induction of hypertension and administration of D-carvone}

Animals were given L-NAME in drinking water at a concentration of $0.4 \mathrm{mg} / \mathrm{ml}$ to account for a daily intake of $40 \mathrm{mg} / \mathrm{kg}$ throughout the experimental period (30 days) (Saravana kumar et al., 2011). D-carvone was suspended in 1\% DMSO just before treatment and administered everyday orally to rats using an intragastric tube at any one of the following doses of 5, 10 and $20 \mathrm{mg} / \mathrm{kg}$ body weight daily for a period of four consecutive weeks. 


\subsection{Experimental timeline}

The rats were randomly divided into six groups each consisting of six rats.

Group I - control rats (animals that received only normal diet and water);

Group II —control + D-carvone $(20 \mathrm{mg} / \mathrm{kg} /$ body weight $)$;

Group III -L-NAME control rats;

Group IV - - L-NAME + D-carvone ( $5 \mathrm{mg} / \mathrm{kg} /$ bodyweight $)$

Group V—L-NAME + D-carvone $(10 \mathrm{mg} / \mathrm{kg} /$ bodyweight $)$

Group VI -L-NAME + D-carvone $(20 \mathrm{mg} / \mathrm{kg} /$ bodyweight $)$.

The experimental duration was 30 days. On 31 st day, the rats were sacrificed by cervical dislocation. Blood was collected (orbital sinus with great care) in a dry test tube and allowed to coagulate at ambient temperature for $40 \mathrm{~min}$. The serum was separated by centrifugation at $224 \times \mathrm{g}$ for $10 \mathrm{~min}$. The blood collected in a heparinized centrifuge tube and centrifuged at $224 \times \mathrm{g}$ for $10 \mathrm{~min}$ and the plasma was separated by aspiration. After the separation of plasma, the buffy coat, enriched in white cells, was removed and the remaining erythrocytes were washed three times with physiological saline. A known volume of erythrocyte was lysed with hypotonic phosphate buffer at $\mathrm{pH} \mathrm{7.4.} \mathrm{The} \mathrm{hemolysate} \mathrm{was}$ separated by centrifugation at $350 \times \mathrm{g}$ for $10 \mathrm{~min}$ and the supernatant was used for the estimation of enzymatic antioxidants.

Aortic tissues were $(250 \mathrm{mg})$ sliced into pieces and homogenized in appropriate buffer in cold condition ( $\mathrm{pH} 7.0)$ to give $20 \%$ homogenate $(\mathrm{w} / \mathrm{v})$. The homogenate was centrifuged at $560 \times \mathrm{g}$ for $10 \mathrm{~min}$ at $4^{\circ} \mathrm{C}$ in refrigerated centrifuge. The supernatant was separated and used for various biochemical estimations.

\subsection{Measurement of blood pressure by non-invasive method}

Before commencement of the experiment, animals were trained with instrument for measuring blood pressure. In all groups of animals, heart rate was recorded every week during the entire period of the study noninvasively using a tail-cuff method according to standard procedures (IITC, model 31, USA). Values reported are the average of three sequential measurements. All the recordings and data analyses were done using a computerized data acquisition system and software.

\subsection{Nitric oxide metabolites level}

Nitrite and nitrate [stable nitric oxide metabolites] in the plasma samples were measured based on the Griess reaction (Green et al., 1982).

\subsection{Estimation of total cholesterol and triglycerides}

Tissue lipids were extracted by the method of Folch et al. (1957) using chloroform: methanol mixture $(2: 1 \mathrm{v} / \mathrm{v})$. The levels of total cholesterol (TC) were estimated by the method of Zlatkis et al. (1953). Lipid extract of $0.5 \mathrm{ml}$ was evaporated to dryness. To this, $5.0 \mathrm{ml}$ of ferric chloride - acetic acid reagent was added. The tubes were mixed well and $3.0 \mathrm{ml}$ of concentrated sulphuric acid $\left(\mathrm{H}_{2} \mathrm{SO}_{4}\right)$ was added. A series of standards containing cholesterol in the range $3-15 \mu \mathrm{g}$ were made up to $5.0 \mathrm{ml}$ with the reagent and a blank containing $5.0 \mathrm{ml}$ of the reagent was prepared. The absorbance was read after 20 minutes at $560 \mathrm{~nm}$. 
The content of triglycerides (TG) was estimated by the method of Fossati and Prencipe (1982). Lipid extract of $0.5 \mathrm{ml}$ was evaporated to dryness. To this, $0.1 \mathrm{ml}$ of methanol was added followed by $4.0 \mathrm{ml}$ of isopropanol. About $0.4 \mathrm{~g}$ of alumina was added to all the tubes and shaken well for 15 minutes. It was centrifuged and then accurately $2.0 \mathrm{ml}$ of the supernatant was transferred to appropriately labeled tubes. The tubes were placed in a water bath at $65^{\circ} \mathrm{C}$ for 60 minutes for saponification after adding $0.6 \mathrm{ml}$ of the saponification reagent followed by $0.1 \mathrm{ml}$ of sodium metaperiodate and $0.5 \mathrm{ml}$ of acetyl acetone reagent. After mixing, the tubes were kept in a water bath at $65^{\circ} \mathrm{C}$ for an hour. A series of standards of concentration 8-40 $\mu \mathrm{g}$ triolein were treated similarly along with a blank containing only the reagents. All the tubes were cooled and read at $405 \mathrm{~nm}$.

\subsection{Estimation of free fatty acids and phospholipids}

Free fatty acid (FFA) level was estimated by the method of Falholt et al. (1973). An aliquot $(0.5 \mathrm{ml})$ of the lipid extract was evaporated to dryness. To this, $1.0 \mathrm{ml}$ of phosphate buffer, $6.0 \mathrm{ml}$ of extraction solvent, and $2.5 \mathrm{ml}$ of copper $(\mathrm{Cu}-\mathrm{TEA})$ reagent were added. All the tubes were shaken vigorously for 90 seconds and were kept aside for 15 minutes. Then the tubes were centrifuged and $3.0 \mathrm{ml}$ of the upper layer was transferred to another tube containing $0.5 \mathrm{ml}$ of diphenylcarbazide solution and mixed carefully. The absorbance was read at $550 \mathrm{~nm}$ after 15 minutes. A reagent blank containing $(1.0 \mathrm{ml})$ of phosphate buffer was processed as blank.

Phospholipid (PL) level was estimated by the method of Zilversmit and Davis (1950). An aliquot of $0.5 \mathrm{ml}$ of the lipid extract was pipetted out into a Kjeldahl flask and evaporated to dryness. To the extract, $1 \mathrm{ml}$ of $5 \mathrm{~N} \mathrm{H}_{2} \mathrm{SO}_{4}$ was added and digested in a digestion rack till the appearance of light brown color. Two to three drops of concentrated nitric acid was added and the digestion continued till it became colorless. The Kjeldahl flask was cooled and $1.0 \mathrm{ml}$ of distilled water was added and heated in a boiling water bath for about 5 minutes. Then, 1.0 $\mathrm{ml}$ of $2.5 \%$ ammonium molybdate and $0.1 \mathrm{ml}$ of 1-amino-2-napthol-4-sulfonic acid were added. The volume was then made upto $5.0 \mathrm{ml}$ with distilled water and the absorbance was measured at $660 \mathrm{~nm}$ within 10 minutes.

\subsection{Determination of enzymatic antioxidants}

Superoxide dismutase (SOD) activity was assayed in the erythrocyte and tissues by the method of Kakkar et al. (1984). Erythrocytes $(0.5 \mathrm{ml})$ were diluted to $1.0 \mathrm{ml}$ with distilled water followed by addition of $2.5 \mathrm{ml}$ of ethanol and $1.5 \mathrm{ml}$ of chloroform (all reagents chilled) was added. This mixture was shaken and then centrifuged. The enzyme activity in the supernatant was determined. The assay mixture contained $1.2 \mathrm{ml}$ of sodium pyrophosphate buffer, $0.1 \mathrm{ml}$ of phenazine methosulphate, and $0.3 \mathrm{ml}$ of nitroblue tetrazolium and appropriately diluted enzyme preparation in a total volume of $3 \mathrm{ml}$. The reaction was started by the addition of $0.2 \mathrm{ml}$ of nicotinamide adenine dinucleotide (NADH). After incubation at $30^{\circ} \mathrm{C}$ for $90 \mathrm{~s}$, the reaction was arrested by the addition of $1.0 \mathrm{ml}$ of glacial acetic acid. The reaction mixture was stirred vigorously and shaken with $4 \mathrm{ml}$ of n-butanol. The mixture was allowed to stand for $10 \mathrm{~min}$; centrifuged and n-butanol layer was separated. The color density of the chromogen in n-butano was measured at $510 \mathrm{~nm}$ against butanol blank.

The activity of catalase (CAT) in the erythrocyte was assayed by the method of Sinha (1972). To $0.9 \mathrm{ml}$ of phosphate buffer, $0.1 \mathrm{ml}$ of erythrocyte and $0.4 \mathrm{ml}$ of $\mathrm{H}_{2} \mathrm{O}_{2}$ were added. The reaction was arrested after $60 \mathrm{~s}$ by adding $2 \mathrm{ml}$ of dichromate-acetic acid mixture. The tubes were kept in a boiling water bath for $10 \mathrm{~min}$ and the color developed was read at $620 \mathrm{~nm}$. 
The activity of glutathione peroxidase (GPx) in the erythrocyte was measured by the method of Rotruck et al. (1973). To $0.2 \mathrm{ml}$ of Tris buffer, $0.2 \mathrm{ml}$ of ethylene diamine tetra acetic acid (EDTA), $0.1 \mathrm{ml}$ of sodium azide, and $0.5 \mathrm{ml}$ of erythrocyte were added. To the mixture, 0.2 $\mathrm{ml}$ of glutathione followed by $0.1 \mathrm{ml}$ of $\mathrm{H}_{2} \mathrm{O}_{2}$ was added. The contents were mixed well and incubated at $37^{\circ} \mathrm{C}$ for $10 \mathrm{~min}$ along with a tube containing all reagents except the sample. After $10 \mathrm{~min}$, the reaction was arrested by the addition of $0.5 \mathrm{ml}$ of $10 \%$ TCA. The tubes were centrifuged and the supernatant was used for the estimation of glutathione.

\subsection{Statistical analysis}

Statistical analysis was performed by one-way analysis of variance followed by Duncan's multiple range test using statistical package for the social science (SPSS) software version 11.5. Results were expressed as mean \pm S.D. for six rats in each group. A value of $\mathrm{P}<0.05$ was considered to be statistically significant.

\section{RESULTS}

\subsection{Effect of D-carvone on heart rate and water intake}

Figs. 1 and 2 shows the effect of D-carvone on heart rate and water intake in control and L-NAME induced hypertensive rats. Heart rate and water intake were increased significantly $(\mathrm{P}<0.05)$ in L-NAME induced hypertensive rats when compared with control. Treatment with Dcarvone $(5,10, \& 20 \mathrm{mg} / \mathrm{kg})$ significantly $(\mathrm{P}<0.05)$ reduced the heart rate and water intake in LNAME induced hypertensive rats. The $20 \mathrm{mg} / \mathrm{kg}$ dose showed better effect in reducing heart rate and water intake than other two doses ( 5 and $10 \mathrm{mg} / \mathrm{kg}$ ), and also in our previous study the 20 $\mathrm{mg} / \mathrm{kg}$ dosage showed higher effect, so we have chosen $20 \mathrm{mg} / \mathrm{kg}$ dosage for further evaluation.

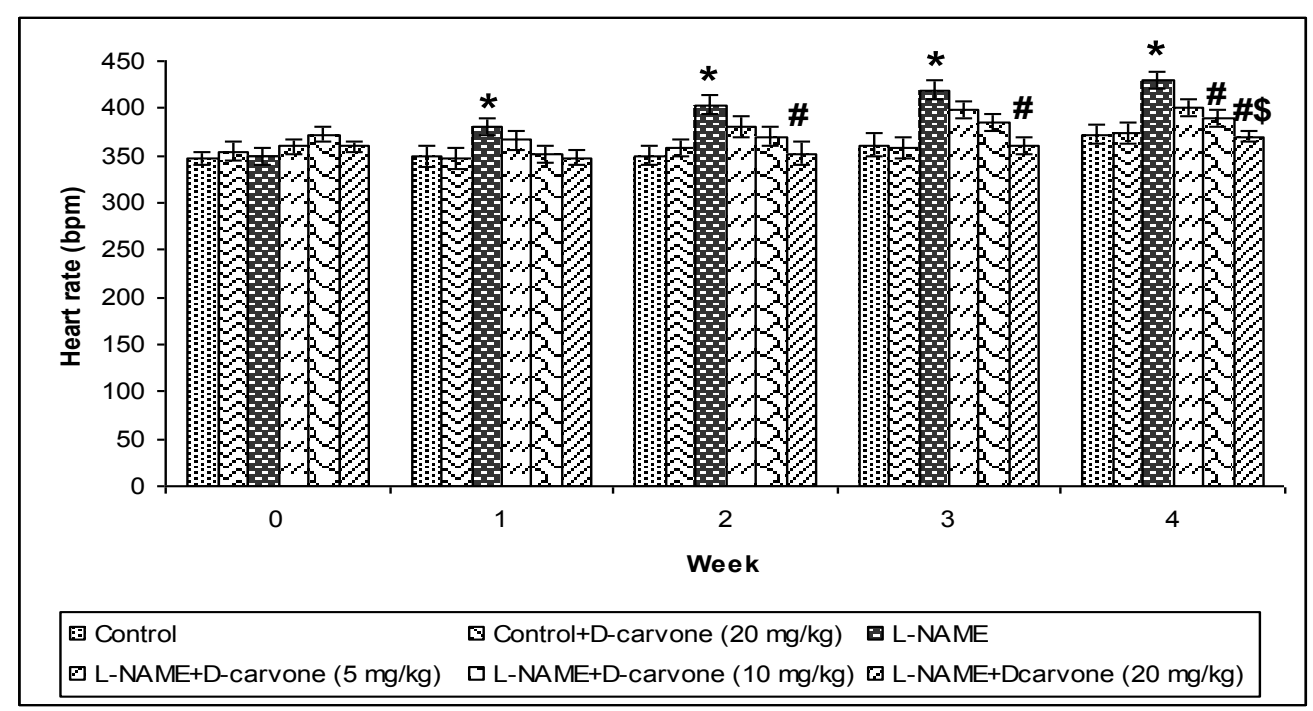

Fig. 1. Effect of D-carvone on heart rate in control and L-NAME induced hypertensive rats. 
Columns are mean \pm S.D. for six rats in each group. Data were analyzed by one-way ANOVA followed by Duncan's multiple range test (DMRT). ${ }^{*} \mathrm{P}<0.05$ compared with the control. \# $\mathrm{P}<0.05$ compared with the L-NAME. ${ }^{\$} \mathrm{P}<0.05$ compared with the D-carvone $(10 \mathrm{mg} / \mathrm{kg})$ group.

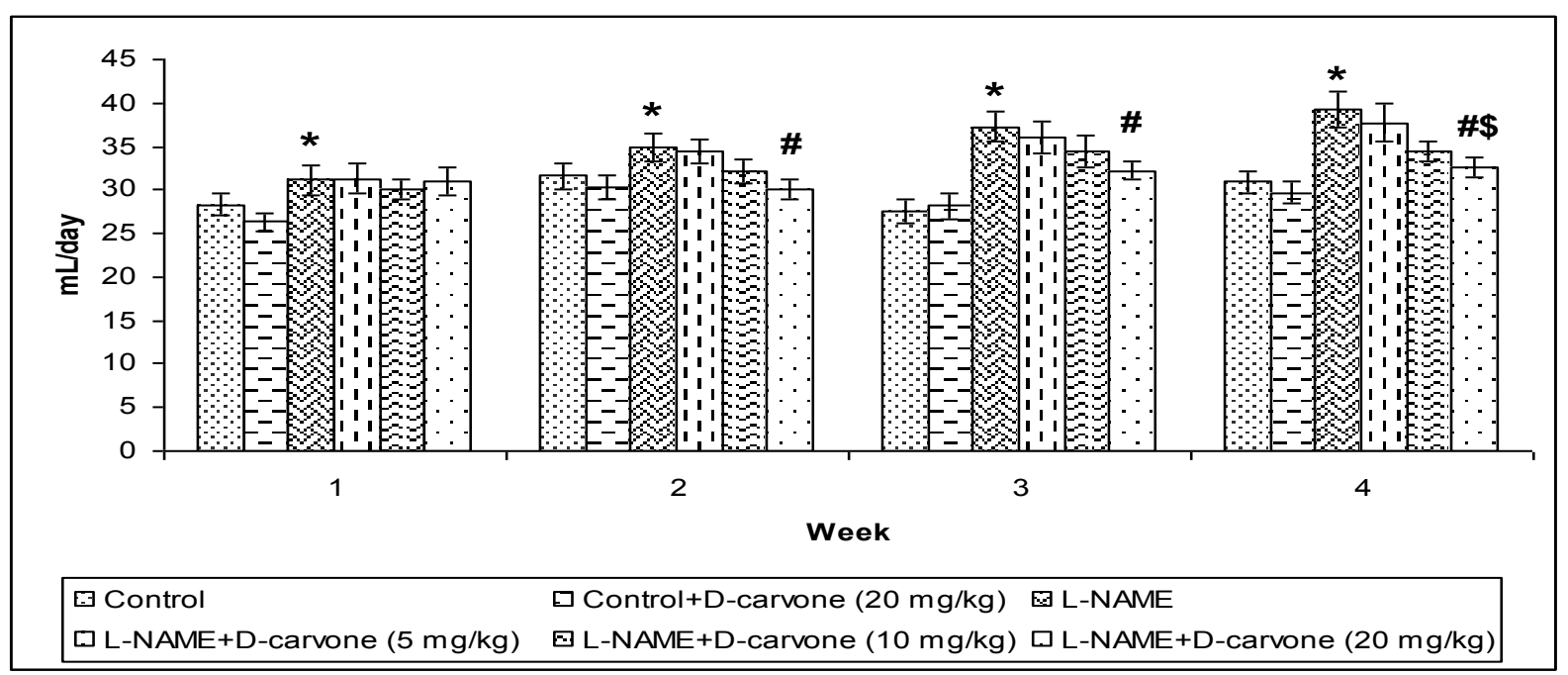

Fig. 2. Effect of D-carvone on water intake in control and L-NAME induced hypertensive rats.

Columns are mean \pm S.D. for six rats in each group. Data were analyzed by one-way ANOVA followed by Duncan's multiple range test (DMRT). ${ }^{*} \mathrm{P}<0.05$ compared with the control. ${ }^{\#} \mathrm{P}<0.05$ compared with the L-NAME. ${ }^{\$} \mathrm{P}<0.05$ compared with the D-carvone (10 $\mathrm{mg} / \mathrm{kg}$ ) group.

\subsection{Effect of D-carvone on aortic lipids}

Table 1 depict the levels of lipids (TC, TGs, FFAs, and PLs) in aorta of control and LNAME hypertensive rats. The levels of lipids $(\mathrm{TC}, \mathrm{TG}$ and FFA) were significantly $(\mathrm{P}<0.05)$ increased and the level of PL was significantly $(\mathrm{P}<0.05)$ decreased in L-NAME hypertensive rats when compared to control rats. Treatment with $\mathrm{D}$-carvone significantly $(\mathrm{P}<0.05)$ declined the levels of TC, TG and FFA, and increased the level of PL in L-NAME hypertensive rats.

Table 1. Effect of D-carvone on lipid profile in aorta of control and L-NAME induced hypertensive rats.

\begin{tabular}{cccccc}
\hline \multicolumn{2}{c}{ Parameter } & Control & Control+D-C & L-NAME & L-NAME+D-C \\
\hline $\begin{array}{c}\text { TC } \\
(\mathrm{mg} / \mathrm{g} \text { tissue })\end{array}$ & Aorta & $3.82 \pm 0.22$ & $2.99 \pm 0.16$ & $5.97 \pm 0.41^{*}$ & $4.12 \pm 0.21^{\#}$ \\
$\begin{array}{c}\text { TG } \\
(\mathrm{mg} / \mathrm{g} \mathrm{tissue})\end{array}$ & Aorta & $2.79 \pm 0.15$ & $2.83 \pm 0.22$ & $4.24 \pm 0.45^{*}$ & $3.02 \pm 0.22^{\#}$ \\
$\begin{array}{c}\text { FFA } \\
(\mathrm{mg} / \mathrm{g} \mathrm{tissue})\end{array}$ & Aorta & $3.82 \pm 0.32$ & $3.99 \pm 0.26$ & $5.26 \pm 0.50^{*}$ & $4.02 \pm 0.32^{\#}$ \\
$\begin{array}{c}\text { PL } \\
(\mathrm{mg} / \mathrm{g} \text { tissue })\end{array}$ & Aorta & $5.43 \pm 0.27$ & $5.76 \pm 0.29$ & $3.66 \pm 0.22^{*}$ & $5.96 \pm 0.56^{\#}$ \\
\hline
\end{tabular}


Columns are mean \pm S.D. for six rats in each group. Data were analyzed by one-way ANOVA followed by Duncan's multiple range test (DMRT). ${ }^{*}<0.05$ compared with the control. ${ }^{\#} \mathrm{P}<0.05$ compared with the L-NAME.

\subsection{Effects of D-carvone on nitric oxide metabolites}

Fig. 3 depicts the levels of nitric oxide metabolites (nitrite and nitrate) in plasma of control and L-NAME induced hypertensive rats. L-NAME induced hypertensive rats had significantly $(\mathrm{P}<0.05)$ decreased levels of total nitrite and nitrate levels in plasma and treatment with $\mathrm{D}$ carvone significantly $(\mathrm{P}<0.05)$ elevated the levels of nitric oxide metabolites.

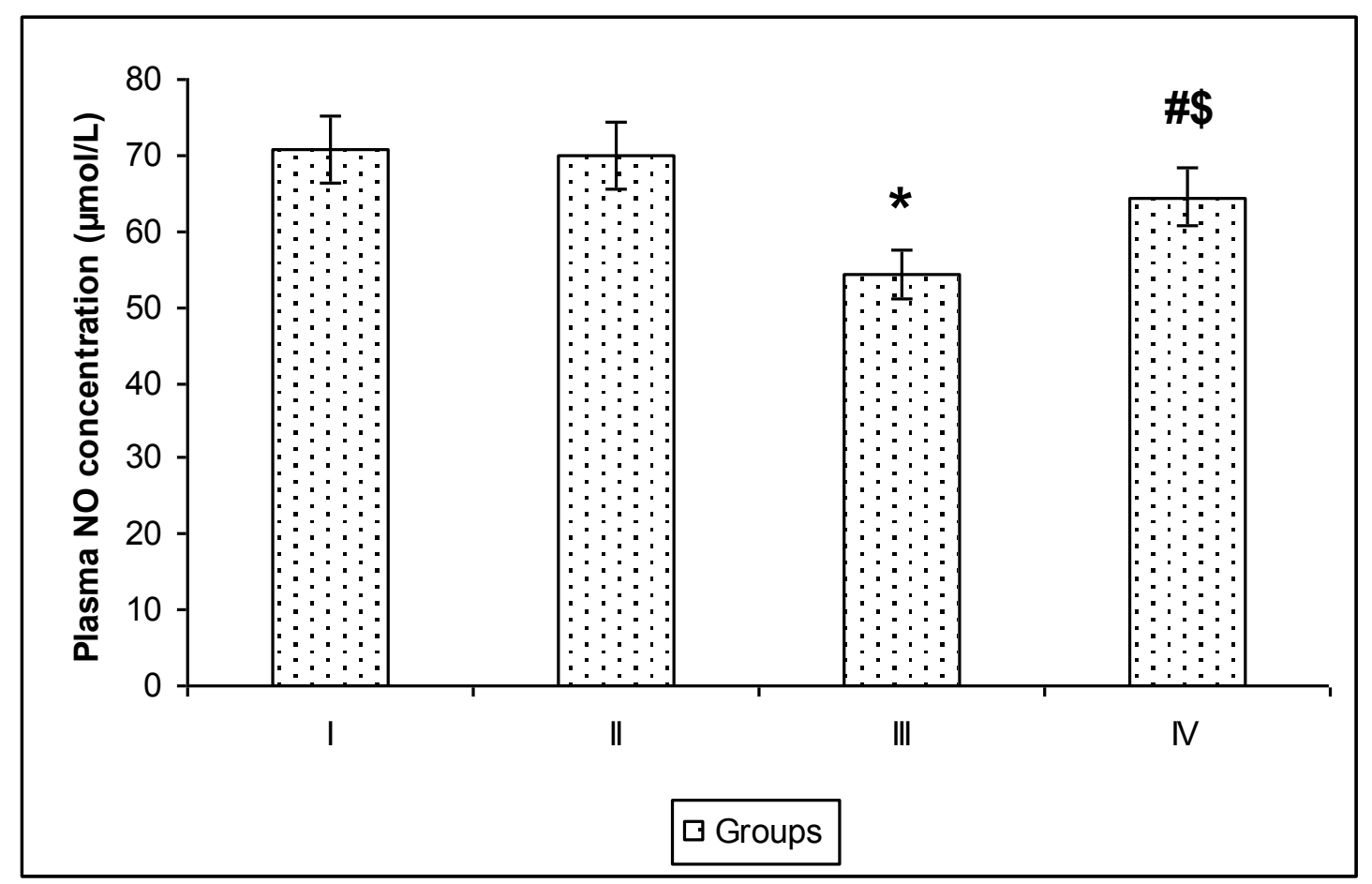

Fig. 3. Effect of D-carvone on plasma NO concentration in control and L-NAME induced hypertensive rats.

Columns are mean \pm S.D. for six rats in each group. Data were analyzed by one-way ANOVA followed by Duncan's multiple range test (DMRT). ${ }^{*}<0.05$ compared with the control. ${ }^{\#} \mathrm{P}<0.05$ compared with the L-NAME.

\subsection{Effect of D-carvone on enzymatic antioxidants}

Table 2 shows the activities of superoxide dismutase, catalase and glutathione peroxidase in erythrocytes of control and L-NAME hypertensive rats. The activities of these enzymatic antioxidants were significantly $(\mathrm{P}<0.05)$ decreased in L-NAME hypertensive rats. Treatment with $\mathrm{D}$-carvone significantly $(\mathrm{P}<0.05)$ restored the activity of these enzymatic antioxidants in erythrocytes of L-NAME hypertensive rats. 
Table 2. Effect of D-carvone on SOD, CAT and GP $\mathrm{X}$ in erythrocytes of control and L-NAME induced hypertensive rats.

\begin{tabular}{|c|c|c|c|c|c|}
\hline \multicolumn{2}{|c|}{ Parameter } & Control & Control+D-C & L-NAME & L-NAME+D-C \\
\hline $\begin{array}{c}\text { Superoxide } \\
\text { dismutase }\end{array}$ & $\begin{array}{l}\text { Erythrocyte } \\
\left(\mathrm{U}^{\mathrm{a}} / \mathrm{mgHb}\right)\end{array}$ & $7.11 \pm 0.52$ & $7.14 \pm 0.63$ & $3.38 \pm 0.37^{*}$ & $6.15 \pm 0.38^{\#}$ \\
\hline Catalase & $\begin{array}{l}\text { Erythrocyte } \\
\left(\mathrm{U}^{\mathrm{b}} / \mathrm{mg} \mathrm{Hb}\right)\end{array}$ & $\begin{array}{c}173.20 \pm \\
9.57\end{array}$ & $174.05 \pm 9.62$ & $99.77 \pm 6.96^{*}$ & $158.03 \pm 7.84^{\#}$ \\
\hline $\begin{array}{l}\text { Glutathione } \\
\text { peroxidase }\end{array}$ & $\begin{array}{l}\text { Erythrocyte } \\
\left(\mathrm{U}^{\mathrm{c}} / \mathrm{mg} \mathrm{Hb}\right)\end{array}$ & $14.12 \pm 0.84$ & $14.43 \pm 0.88$ & $6.98 \pm 0.59^{*}$ & $12.05 \pm 0.49^{\#}$ \\
\hline
\end{tabular}

$\mathrm{U}^{\mathrm{a}}$, enzyme concentration required to inhibit the chromogen produced by $50 \%$ in one minute under standard condition. $\mathrm{U}^{\mathrm{b}}, \mu$ mole of $\mathrm{H}_{2} \mathrm{O}_{2}$ consumed/minute. $\mathrm{U}^{\mathrm{c}}, \mu \mathrm{g}$ of $\mathrm{GSH}$ utilized/minute. Values are mean \pm S.D. for six rats in each group. Data were analyzed by one-way ANOVA followed by Duncan's multiple range test (DMRT). ${ }^{*}<0.05$ compared with the control. ${ }^{\#} \mathrm{P}<0.05$ compared with the L-NAME.

\section{DISCUSSION}

The main vaso-relaxing factor produced by endothelial cells is nitric oxide. It is synthesized from L-arginine by the action of endothelial nitric oxide synthase and is important for the regulation of blood pressure (Moncada and Higgs, 1993). Arterial hypertension, an important risk factor of cardiovascular diseases, is characterized by production of excessive reactive oxygen species interacting with $\mathrm{NO}$ and reducing its bioavailability; oxidation of NO to peroxynitrite by reactive oxygen species induces oxidative stress (De Gennaro Colonna et al., 2005). Chronic inhibition of NO produces volume-dependent elevation of blood pressure; and its physiological and pathological characteristics resemble essential hypertension (Attia et al., 2001). Besides, it is well established that acute inhibition of NO biosynthesis by in vivo administration of L -NAME, an L-arginine analog, leads to arterial hypertension and vasoconstriction (Attia et al., 2001). Several studies related to experimental hypertension showed that an increase in arterial blood pressure reduces circulatory nitric oxide, which reflects the role of arginine-nitric oxide in the pathophysiology of hypertension (Dryden et al., 2005). Our findings show that L-NAME-treated rats showed significantly increased heart rate and water intake. Treatment with D-carvone significantly reduced the heart rate and water intake that may be due to increasing the bioavailability of nitric oxide and antioxidant actions of D-carvone (Johri, 2011).

The presence of high BP and hyperlipidemia is so common in hypertension that many have argued that the high BP itself may play a role in altering lipid metabolism, resulting in abnormalities (Friedwald et al., 1972a,b). The blockade of NO synthase by L-NAME seems to be involved in lipid metabolism alterations: increases serum/plasma cholesterol levels in rats (Khedara et al., 1996). Hypercholesterolemia and hypertriglyceridemia were seen in nitric oxide-deficient rats which might be due to increased mobilization of lipids from liver and kidney tissues (Saravana kumar et al., 2010; Saravana kumar and Raja, 2012). Elevated total 
cholesterol (TC) levels augment the risk of cardiovascular disease associated with hypertension. Elevated cholesterol levels predispose to a condition known as hypercholesterolemia. Large epidemiologic studies have demonstrated that subjects with hypertension have a marked increase in the prevalence of hypercholesterolemia (Yang et al., 2011). The observed increase in TGs might be due to a decrease in the activity of lipoprotein lipase, resulting in decreased uptake of TGs from the circulation (Casazza et al., 2009).

Hypertension frequently coincides with elevated levels of triglycerides (TGs). Very low density lipoprotein-cholesterol (VLDL-C) is the major transport vehicle for the TGs from the liver to extra hepatic tissues, whereas low density lipoprotein-cholesterol (LDL-C) is not secreted as such the liver; rather, it seems to be formed from VLDL-C after partial removal of TGs by lipoprotein lipase (Mayes, 1997). Fatty acids play a key role in the formation and maintenance of all cells and PL are the major structural components of intracellular membranes in all living organisms. Abnormalities in fatty acids and phospholipid metabolism are important in the pathogenesis of cell membrane dysfunction (Saravana kumar et al., 2010). Our results showed a decrease in the levels of TC, TG, FFA and increase in the level of PL in L-NAME hypertensive rats after treatment with D-carvone.

Nitric oxide synthesized by endothelial NO synthase (eNOS) is a major regulator of the vascular tone. Arterial hypertension, an important risk factor of cardiovascular diseases, is characterized by production of extra amount of reactive oxygen species (ROS) interacting with NO and reducing its bioavailability; oxidation of NO to peroxynitrite by ROS induces oxidative stress (De Gennaro Colonna et al., 2005). In addition, decrease in eNOS activity leads to a decrease in NO bioavailability (Rybka et al., 2011). It suggests that dysfunction of NO pathway in hypertensive subjects is a consequence rather than a cause of elevated blood pressure (Boulanger, 1999). In addition, NO has been identified as important in other cellular events, such as a vascular smooth muscle cell proliferation (Nguelefack-Mbuyoa et al., 2008). In this study we demonstrated that treatment with chronic inhibition of NOS by L-NAME rats significantly decreased plasma NOx levels. Treatment with D-carvone improved plasma NOx levels in L-NAME rats, effects that may be attributed to its antioxidant properties.

Superoxide dismutase, catalase and glutathione peroxidase balance together to eliminate reactive oxygen species, and small deviations in physiological concentrations may have a dramatic effect on the resistance of cellular lipids, proteins, and DNA to oxidative damage (Mates and Sanchez-Jimenez, 1999). SOD plays an important role in scavenging superoxide anion, which is the initial free radical, among the oxygen radicals. Catalase prevents oxidative hazard by catalyzing the formation of water and oxygen from hydrogen peroxide (Rajeshkumar and Kuttan, 2003). GPx offers protection to the cellular and subcellular membranes from the peroxidative damage by eliminating hydrogen peroxide by utilizing reduced glutathione and $\mathrm{H}_{2} \mathrm{O}_{2}$ as substrates to yield $\mathrm{H}_{2} \mathrm{O}$ and oxidized glutathione and its declined activity may be due to the reduced availability of GSH (Li et al., 2012). In consistency with the previous reports, L-NAME induced hypertensive rats showed significantly depleted levels of antioxidant enzymes in tissues (Kumar et al., 2011; Saravanakumar and Raja, 2011). Administration of D-carvone, improved the activities of enzymatic antioxidants in L-NAME induced hypertensive rats. The increased activities of these enzymic antioxidants in D-carvone treated rats might be due to the increased nitric oxide metabolites which could exert a beneficial action against pathophysiological alterations caused by superoxide anion and hydroxyl radicals. 
Major findings from the present study confirmed that D-carvone supplementation could effectively prevent the development of hyperlipidemia in L-NAME rats. Our findings also illustrate that the aorta damage was ameliorated by D-carvone supplementation.

\section{References}

[1] Attia DM, Verhagen AM, Stroes ES. Vitamin E alleviates renal injury, but not hypertension, during chronic nitric oxide synthase inhibition in rats. J. Am. Soc.Nephrol. 2001;12:2585-2593.

[2] Beswick RA, Dorrance AM, Romulo Leite RC. NADH/NADPH oxidase and enhanced superoxide production in the mineralocorticoid hypertensive rat. Hypertension 2001;38: 1107-1111.

[3] Boulanger CM. Secondary endothelial dysfunction: hypertension and heart failure. Journal of Molecular and Cellular Cardiology 1999;31:39-49.

[4] Casazza K, Natour N, Divers J, Vaughan LK, Bigham AW, Gower BA, et al. Triglyceride concentration is independently associated with variation in the LPL gene in african american and european american women, Open Obes. J. 2009;1: 23-31.

[5] Chang T, Wu L. Methylglyoxal, oxidative stress and hypertension. Canadian Journal of Physiology and Pharmacology 2006;84:1229-38.

[6] De Gennaro Colonn a V, Rigamonti A, Fioretti S, Bo-nomo S, Manfredi B, Ferrario P. Angiotensin-converting enzyme inhibition and angiotensin AT1-receptor antagonism equally improve endothelial vasodilator function in L-NAME-induced hypertensive rats. Eur. J. Pharmacol. 2005;516:253 -259.

[7] Dias-Junior CA, Cau SB, Tanus-Santos JE. Role of nitric oxide in the control of the pulmonary circulation: physiological, pathophysiological, and therapeutic implications. J Bras Pneumol 2008;34:412-419.

[8] Diebolt M, Bucher B and Andriantsitohaina R. Wine polyphenols decrease blood pressure, improve NO vasodilatation, and induce gene expression. Hypertension. 2001;38(2):159-165.

[9] Dryden GW Jr, Deaciuc I, Arteel G, McClain CJ. Clinical implications of oxidative stress and antioxidant therapy,Curr. Gastroenterol. Rep. 2005;7:308-316.

[10] Falholt K, Lund B, Falholt W. An easy colorimetric micro method for routine determination of free fatty acids in plasma. Clin. Chim. Acta. 1973;46,105-1.

[11] Folch J, Lees M, Sloane Stanly GH. A simple method for the isolation and purification of total lipids from animal tissues. J Biol Chem 1957;226:497-509.

[12] Fossati P, Prencipe L. Serum triglycerides determined colorimetrically with an enzyme that produces hydrogen peroxide. Clin. Chem 1982;28:2077-80. 
[13] Friedwald WT, Levy RJ, Fredricken DS. Estimation of the concentration of LDL cholesterol in the plasma without the use of preparative ultracentrifuge. Clin. Chem.1972b;18:499-502.

[14] Friedwald WT, Levy RJ, Fredricken DS. Estimation of VLDL-cholesterol in the plasma without the use of preparative ultracentrifuge. Clin. Chem. 1972a;18,449.

[15] Grassi D, Lippi C, Necozione S, Desideri G and Ferri C. Short-term administration of dark chocolate is followed by a significant increase in insulin sensitivity and a decrease in blood pressure in healthy persons. The American Journal of Clinical Nutrition. 2005;81 (3):611-614.

[16] Green LC, Wagner DA, Glogowski J, Skipper PL, Wishnok JS, Tannenbaum SR. Analysis of nitrate, nitrite, and [15 N] nitrate in biological fluids. Anal Biochem 1982;126:131-8.

[17] Gu D, Reynolds K, Wu X, Chen J, Duan X, Muntner P, Huang G, Reynolds RF, Su S, Whelton PK, He J. Prevalence, awareness, treatment, and control of hypertension in china. Hypertension 2002;40:920-927.

[18] Johri RK. Cuminumcyminum and Carumcarvi: An update. Pharmacogn Rev 2011;5:63-72.

[19] Kakkar P, Das B, Viswanathan PN. A modified spectrophotometric assay of superoxide dismutase. Indian J Biochem Biophys 1984;21:130-132.

[20] Khedara A, Kawai Y, Kayashita K, Kat N. Feedeing rats the nitric oxide synthase inhibitor, $\mathrm{L}-\mathrm{N}^{\omega}$ nitro arginine, elevates serum triglyceride and cholesterol and lowers hepatic fatty acid oxidation,J. Nutr. 1996;126:2563-2567.

[21] Kumar S, Prahalathan P, Raja B. Antihypertensive and antioxidant potential of vanillic acid, a phenolic compound in L-NAME induced hypertensive rats: a dose-dependence study. Redox Report 2011;16:208-215.

[22] Kumar S, Saravanakumar M, Raja B. Efficacy of piperine, an alkaloidal constituent of pepper on nitric oxide, antioxidants and lipid peroxidation markers in L-NAME induced hypertensive rats. Int J Res Pharm Sci 2010;1:300-307.

[23] Li H, Xie YH, Yang Q, Wang SW, Zhang BL, et al. Cardioprotective effect of paeonol and danshensu combination on isoproterenol-induced myocardial injury in rats, PLoS ONE. 2012; doi:10.1371/journal.pone.0048872.

[24] Mates JM, Sanchez-Jimenez F. Antioxidant enzymes and their implications in pathophysiologic processes. Frontiers in Bioscience 1999;4:339-345.

[25] Mayes PA, Metabolism of Lipids, In: Harper HA, Rodwell VW, Mayes PA, Reviews of physiological chemistry, Lange publications, LosAltos, 1997;280-321.

[26] Moncada S, Higgs A. The L-arginine- nitric oxid e pathway. N. Engl. J. Med. 1993;329: 2002-2012.

[27] Muruganathan U, Srinivasan S, Indumathi D. Antihyperglycemic effect of carvone: Effect on the levels of glycoprotein components in streptozotocin-induced diabetic rats. Journal of Acute Disease. doi: 10.1016/S2221-6189(13)60150-X. 
[28] Nguelefack-Mbuyoa PE, Nguelefackb TB, Dongmoc B, Afkird S, Azebazee AGB, Dimoa T, Legssyerd A, Kamanyi A, Ziyyat A. Anti hypertensive effects of the methanol/methylene chloride stem bark extract of mammea africana in L-NAMEinduced hypertensive rats. Journal of Ethnopharmacology 2008;117:446-450.

[29] Palmieri VO, Grattagliano I, Portincasa P. Systemic oxidative alterations are associated with visceral adiposity and liver steatosis in patients with metabolic syndrome. J Nutr 2006;136:3022-26.

[30] Rajeshkumar NV, Kuttan R. Modulation of carcinogenic response and antioxidant enzymes of rats administered with 1,2-dimethylhydrazine by Picroliv, Cancer Lett. 2003;191:137-43.

[31] Rotruck JT, Pope AL, Ganther HE, Swanson AB, Hafeman DG, Hoekstra WG. Selenium: biochemical role as a component of glutathione peroxidase. Science 1973;179:588-590.

[32] Rybka J, Kupczyk D, Kcdziora-Kornatowska K, et al. Glutathione related antioxidant defense system in elderly patients treated for hypertension. Cardiovascular Toxicology 2011;11:1-9.

[33] Saravana kumar M, Kumar S, Raja B. Antihypertensive and antioxidant potential of borneol-a natural terpene in L-NAME induced hypertensive rats. Int. J. Pharm and Biol Arch. 2010;1:271-279.

[34] Saravanakumar M, Raja B. Effect of veratric acid on the cardiovascular risk of LNAME-induced hypertensive rats,J. Cardiovasc. Pharmacol. 2012;59:553-562.

[35] Saravanakumar M, Raja B. Veratric acid, a phenolic acid attenuates blood pressure and oxidative stress in L-NAME induced hypertensive rats. Eur J Pharmacol 2011;671:87-94.

[36] Sinha AK. Colorimetric assay of catalase. Anal Biochem 1972;47:389-394.

[37] Thakali K, Davenport L, Fink GD, Watts WS. Pleiotropic effects of hydrogen peroxide in arteries and veins from normotensive and hypertensive rats. Hypertension 2006;47:482-487.

[38] Vinothkumar R, Sudha M, Viswanathan P, Kabalimoorthy J, Balasubramanian T, Nalini N. Modulating effect of D-carvone on 1,2-dimethylhydrazine induced preneoplastic lesions, oxidative stress and biotransforming enzymes in an experimental model of rat colon carcinogenesis. Cell Proliferation 2013;46:705-720.

[39] Whitworth JA. World Health Organization, International Society of Hypertension Writing Group. 2003 World Health Organization (WHO)/International Society of Hypertension (ISH) statement on management of hypertension. $J$ Hypertens 2003;21:1983-92.

[40] Wong ND, Lopez V, Tang S, Williams GR. Prevalence, treatment, and control of combined hypertension and hypercholesterolemia in the United States. Am J Cardiol 2006;98:204-8. 
[41] Yang Y, Li JX, Chen JC, Cao J, Lu XF, Chen SF, et al. Effect of elevated total cholesterol level and hypertension on the risk of fatal cardiovascular disease: a cohort study of Chinese steel workers, Chin. Med. J. (Engl). 2011;124:3702-3706.

[42] Zilversmit DB, Davis AK. Micro determination of plasma phospholipids by trichloroacetic acid precipitation. J. Lab. Clin. Med. 1950;35:155-60.

[43] Zlatkis A, Zak B, Boyle AJ. A new method for the direct determination of serum cholesterol. J. Lab. Clin. Med 1953;41:486-92. 